\title{
FIRST RECORDS OF VIVIPARUS ACEROSUS (BOURGUIGNAT, 1862) (GASTROPODA: VIVIPARIDAE) FROM THE CZECH REPUBLIC OUTSIDE ITS NATIVE RANGE
}

\author{
LUBOŠ BERAN ${ }^{*}$, MiCHAL HORSÁK ${ }^{2}$, SEBASTIAN HOFMAN ${ }^{3}$
}

\author{
${ }^{1}$ Nature Conservation Agency of the Czech Republic, Regional Office Kokořínsko - Máchův kraj Protected \\ Landscape Area Administration, Česká 149, CZ-27601 Mělnik, Czech Republic \\ (e-mail: lubos.beran@nature.cz); (1) https://orcid.org/0000-0002-5851-6048 \\ ${ }^{2}$ Department of Botany and Zoology, Masaryk University, Kotlářská 2, CZ-611 37 Brno, Czech Republic; \\ (1) https://orcid.org/0000-0003-2742-2740 \\ ${ }^{3}$ Department of Comparative Anatomy, Institute of Zoology and Biomedical Research, Jagiellonian \\ University, Gronostajowa 9, 30-387 Cracow, Poland; \\ (1) https://orcid.org/0000-0001-6044-3055 \\ *corresponding author
}

\begin{abstract}
Three native species of the Viviparidae are known in the Czech Republic, namely Viviparus acerosus, $V$. contectus and $V$. viviparus. The native range of $V$. acerosus includes the Danube and probably Dnieper and Dvina river basins. In the Czech Republic it inhabits slowly flowing rivers and canals in the floodplain of the Dyje and Morava rivers in South Moravia (Danube River basin). Recently, this species was found outside its native range in four sites in Bohemia (Labe River basin) and in one site in Silesia (Odra River basin). The species identity of the abundant population from the Svihov dam reservoir (Labe River basin) was verified using COI sequences. These finds represent the first records of the species in the Labe and Odra river basins. The possible origin of these populations is discussed.
\end{abstract}

KEY WORDS: Viviparus acerosus, Czech Republic, non-native occurrence, new records, recent spread

\section{INTRODUCTION}

There are three native species of the Viviparidae reported from the Czech Republic (BERAN 2002, HORSÁK et al. 2013). Viviparus contectus (Millet, 1813) inhabits stagnant waters in the floodplains of large lowland rivers in the Labe, Odra and Danube river basins, while V. viviparus (Linnaeus, 1758) was known in the Czech Republic only from rivers of the Labe River basin (BERAN 2002). Recently, probably native populations of the latter species have been discovered also in the upper section of the Dyje River (Danube River basin) at the boundary between Austria and the Czech Republic (BERAN 2013). The third spe- cies, $V$. acerosus Bourguignat, 1862, typically inhabits slow-flowing rivers and canals in the floodplain of the Dyje and Morava rivers in South Moravia, also parts of the Danube River basin (BERAN 2002, 2013). The species is considered endemic to the Danube and probably also Dnieper and Dvina river basins (VAVROVA \& VAN DAMME 2011, WELTER-SCHULTES 2012, VINARSKI \& KANTOR 2016) (Fig. 1). However, it has been recently found outside its native range, for example in the Netherlands (SOES et al. 2009). In this paper, we present and discuss the first records of this species in the Czech Republic outside its native range. 


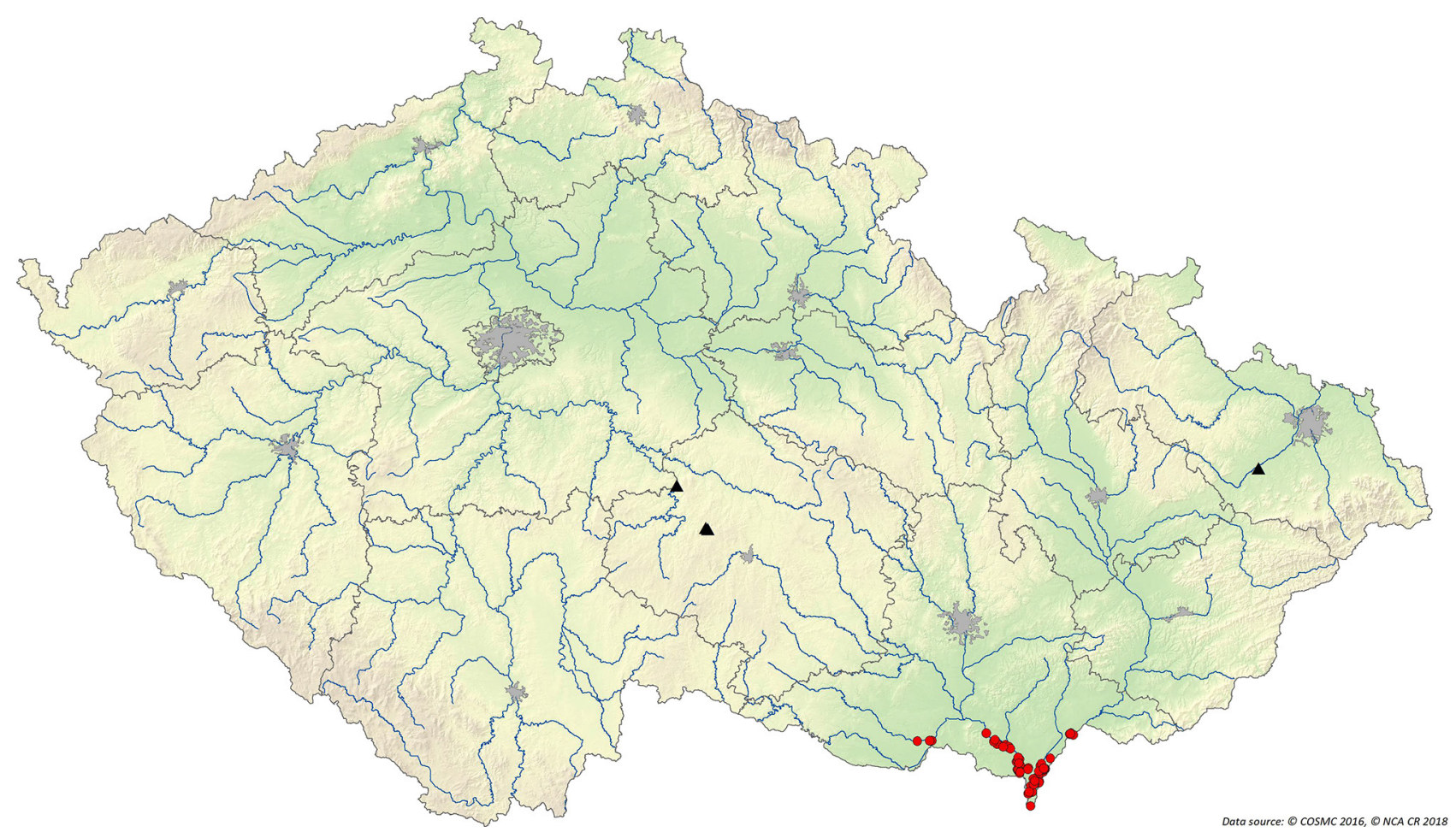

Fig. 1. Map of the Czech Republic with the known occurrence of Viviparus acerosus. Red dots - native occurrence, black triangles - records outside native range. Drawn by J. VRBA

\section{MATERIAL AND METHODS}

The material used in this study was collected by hand with searching of sediments, vegetation and surfaces of stones, wood and artificial materials. The snails for DNA analysis were fixed in $80 \%$ pure ethanol and DNA was extracted from foot tissue. The tissue was hydrated in TE buffer $(3 \times 10 \mathrm{~min}$.); then total genomic DNA was extracted with the SHERLOCK extracting kit (A\&A Biotechnology) and the final product was dissolved in $20 \mu \mathrm{l}$ TE buffer. Details of PCR conditions, primers used and sequencing as well as of phylogenetic analysis were given in SZAROWSKA et al. (2016) and RYSIEWSKA et al. (2019). The following COI sequences from GenBank were used as references: KY781182 (deposited by DAVID et al. 2017) and MK517417, MK517418, MK517420, MK517421, MK517423-MK5174427 (RYSIEWSKA et al. 2019). Two new sequences MN272426-MN272427 obtained from specimens of the site Tvrdonice were also added to GenBank. We used COI sequences only, because other loci were monomorphic for Viviparus. Selected material of shells and/or specimens fixed in $80 \%$ ethanol is deposited in the authors' collections.

\section{RESULTS AND DISCUSSION}

The first locality of $V$. acerosus outside the Danube River basin was found in the Švihov (Želivka) dam reservoir in 2015 (Figs 2, 4, 6). An abundant population was recorded in one site $\left(49^{\circ} 37^{\prime} 25.2^{\prime \prime} \mathrm{N}\right.$, $15^{\circ} 14^{\prime} 52.5 " \mathrm{E}$, 2.8.2015, 15.9.2018, L. BERAN leg.). The collected material was originally identified as $V$. viviparus (BERAN 2017). Both species are morphologically similar and their populations are very variable in size. The pointed apex of $V$. acerosus, which in the field is the most useful feature distinguishing it from $V$. viviparus with blunt apex, is in the case of adult individuals very often difficult to use due to corrosion. Later revision and also COI sequences showed

that this population actually belonged to $V$. acerosus. Our analysis indicated that snails from Švihov and Tvrdonice ( $V$. acerosus from the native range in the Danube River basin) were distinct from other the Viviparus species (Fig. 3), including V. contectus (p-distance 0.115 ) and V. viviparus (p-distance also 0.115). The sequences from Švihov and Tvrdonice were almost identical (1\% differences) and represented one species. Another two populations of this species were found also in two ponds (Sýkora pond, $49^{\circ} 29^{\prime} 32.4^{\prime \prime} \mathrm{N}$, $15^{\circ} 23^{\prime} 12.7 " E$, 4.6.2016, L. BERAN leg., Tuksa pond, $49^{\circ} 29^{\prime} 15.9^{\prime \prime} \mathrm{N}, 15^{\circ} 23^{\prime} 52.3 " \mathrm{E}, 4.6 .2016,15.9 .2018$, L. BERAN leg., Fig. 7), only about $18 \mathrm{~km}$ away from 

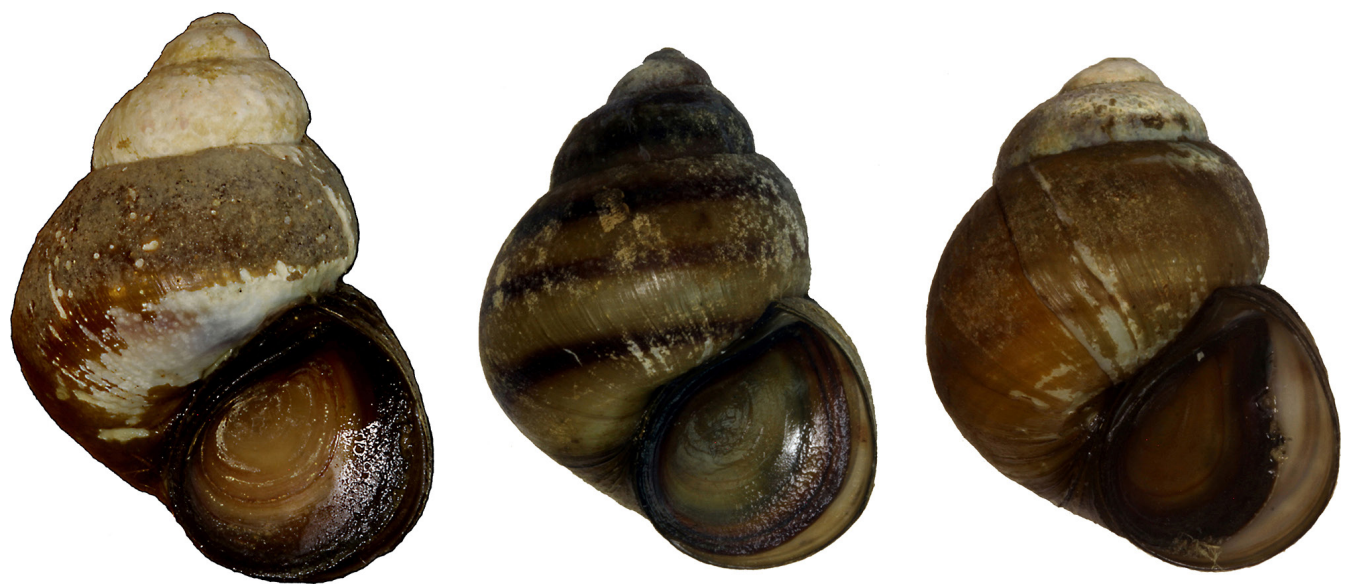

Fig 2. Viviparus acerosus from the Švihov dam reservoir. Photo: ALEKSANDRA RYSIEWSKA

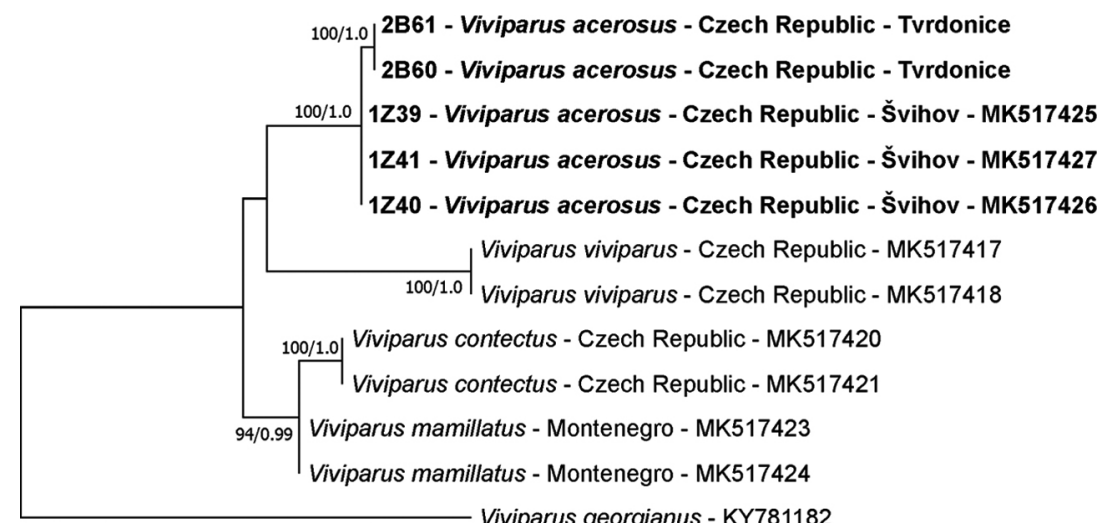

$\longmapsto 0.050$

Fig. 3. Cytochrome oxidase subunit I (COI) maximum likelihood tree; bootstrap supports and Bayesian probabilities and GenBank numbers were given

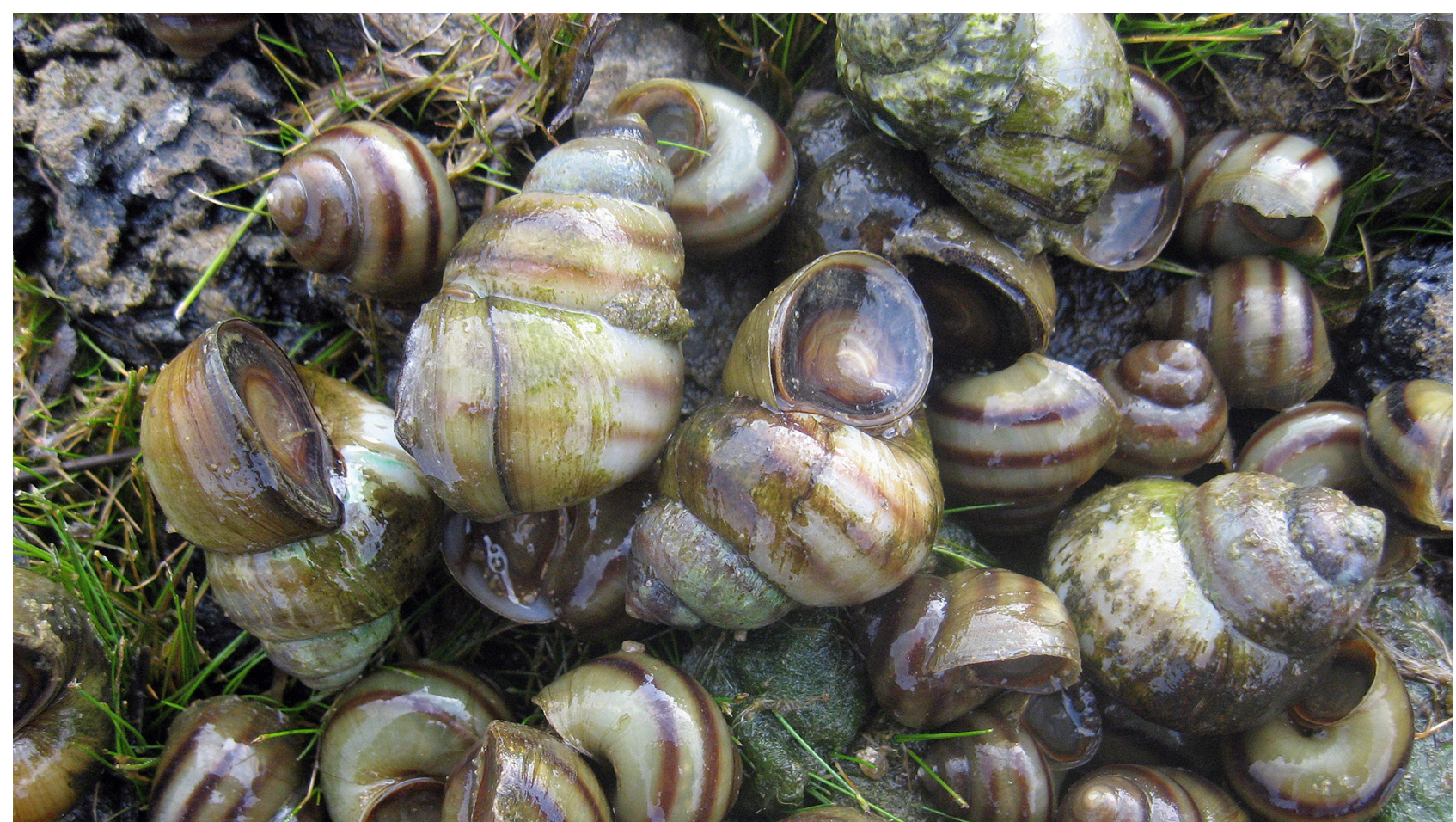

Fig. 4. Live specimens of $V$. acerosus collected at the Švihov dam reservoir. Photo: LUBOš BERAN 


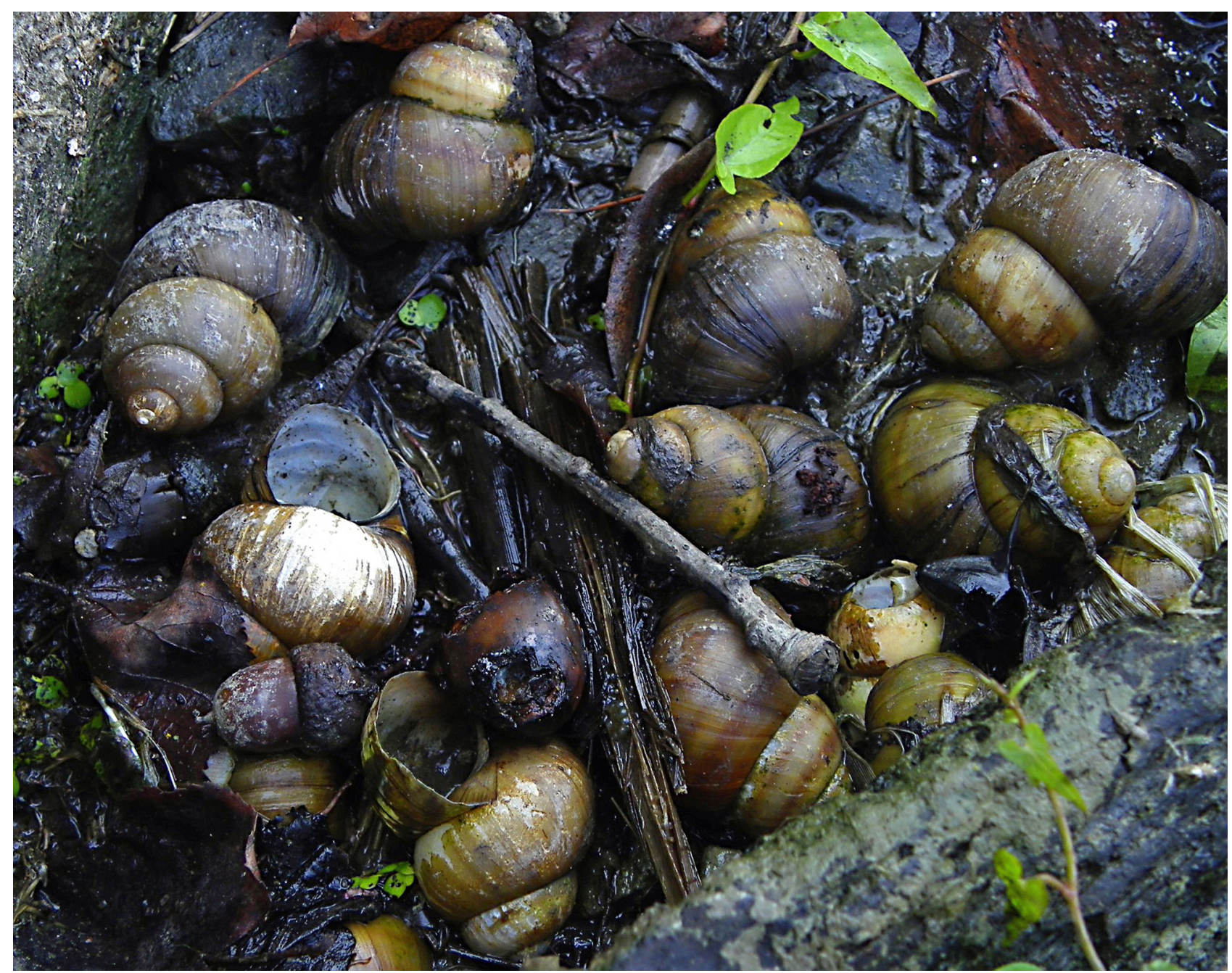

Fig. 5. Accumulation of fresh empty shells of $V$. acerosus at the Horní Bartošovický rybník pond (Silesia). Photo: IVA POSPÍŠILOVÁ

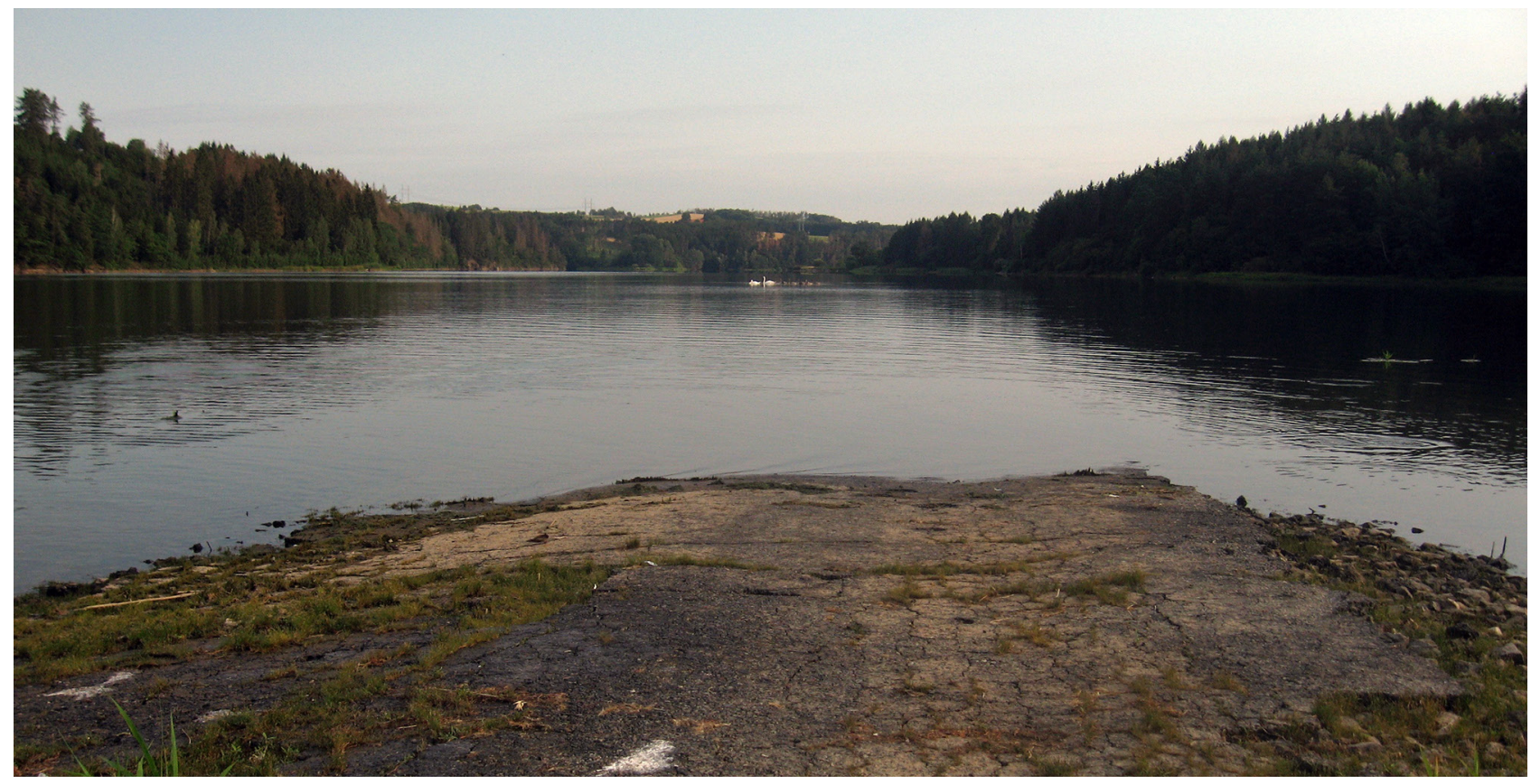

Fig. 6. Švihov dam reservoir. Photo: LUBOŠ BERAN 


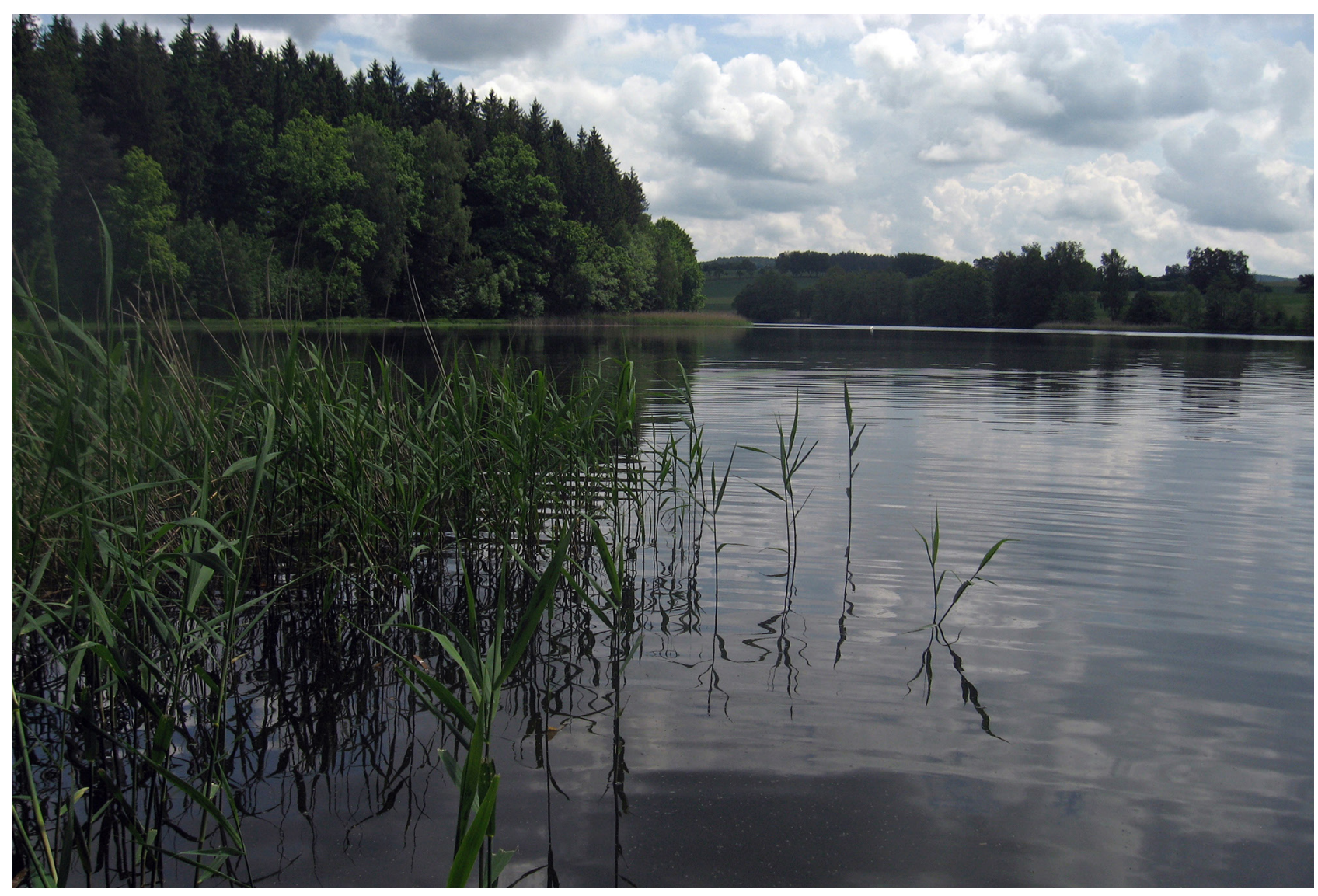

Fig. 7. Tuksa Pond. Photo: LuBoš BerAN

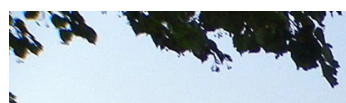

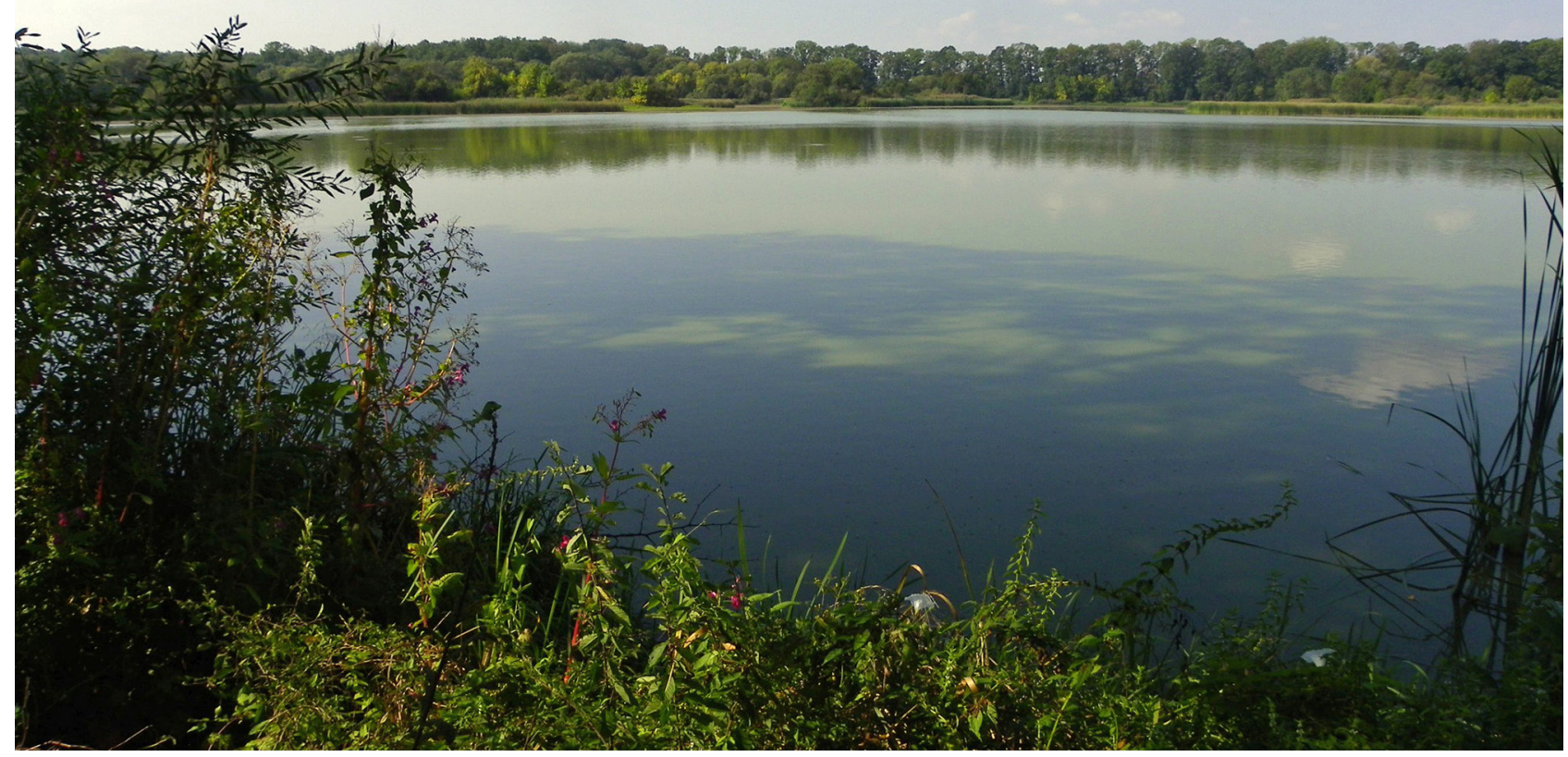

Fig. 8. Horní Bartošovický rybník Pond. Photo: IVA POsPíšslLovÁ 
the first mentioned locality. In the case of the extensive Švihov dam reservoir (1,602 ha) other six sites were surveyed between 2015 and 2019 and V. acerosus was found in one other site only $\left(49^{\circ} 36^{\prime} 51.5^{\prime \prime} \mathrm{N}\right.$, $15^{\circ} 15^{\prime} 10^{\prime \prime E}$, 25.7.2019, L. BERAN leg.). Suprisingly, an abundant population of this species was also found in the pond of Horní Bartošovický rybník in the Poodŕi Protected Landscape Area in the Odra River basin in Silesia $\left(49^{\circ} 40^{\prime} 38.6^{\prime \prime} \mathrm{N}, 18^{\circ} 01^{\prime} 44.9^{\prime \prime} \mathrm{E}\right.$, 5.9.2018, M. HorsÁK leg., Figs 5 and 8). These new records outside the native range represent the first records of this species from the Labe and Odra river basins (Fig. 1).

The origin of these populations can be only deduced. This species (and other species of the Viviparidae) are often sold in garden centres and pet shops, so the first possible way might be an accidental escape from garden pools or a deliberate release. This way is mentioned as the most likely explanation for the occurrence of $V$. acerosus in Dordrecht in the Netherlands (SOES et al. 2009). As gastropods are capable to passive dispersal by birds over long distances, natural dispersal cannot be ruled out either. The nearest sites with the native populations of this gastropod are ca. $123 \mathrm{~km}$ and $105 \mathrm{~km}$ away from the sites in Bohemia in the Labe River basin and ca. $110 \mathrm{~km}$ away from the Horní Bartošovický rybník pond in Silesia. This site is near the boundary with Poland, but $V$. acerosus has not been reported yet from Poland (PIECHOCKI \& WAWRZYNIAKWYDROWSKA 2016). Thus, the nearest populations are known also only from South Moravia. The future population dynamic and even the species presence at these newly colonised sites are hard to predict. In the case of ponds, populations are affected adversely by water level manipulation. This is probably the case of a large extinction recorded in the Tuksa Pond. In 2016, a very abundant population was found there,

\section{REFERENCES}

BERAN L. 2002. Vodní měkkýši České republiky - rozšíření a jeho změny, stanoviště, šíření, ohrožení a ochrana, červený seznam. Sborník přírodovědného klubu v Uh. Hradišti, Supplementum 10. Přírodovědný klub v Uherském Hradišti, Uherské Hradiště.

BERAN L. 2013. Freshwater molluscs of the Dyje (Thaya) river and its tributaries - the role of these water bodies in expansion of alien species and as a refuge for endangered gastropods and bivalves. Folia Malacologica 21: 143-160. http://doi.org/10.12657/folmal.021.018

BERAN L. 2017. Vodní měkkýši Vysočiny. Malacologica Bohemoslovaca 16: 44-76.

David A. A., Zhou H., LeWIS A., YhanN A., Verra S. 2017. DNA Barcoding of the Banded Mystery Snail, Viviparus georgianus in the Adirondacks with quantifi- while during the visit in 2018 only empty shells were recorded. Eutrophication may also have a negative effect on pond populations. However the situation in the Švihov dam reservoir is probably different. The reservoir serves as a source of drinking water and thus the quality of the environment is relatively well secured and stable. The reservoir is also inhabited by an abundant population of the invasive Dreissena polymorpha (Pallas, 1771), however no effect on the population of $V$. acerosus was observed (sessile specimens of $D$. polymorpha were found only on empty shells of $V$. acerosus) and the changes in the water level have caused extinction of only a part of the population. The question is whether the species will spread because it has been found in the reservoir only in two sites out of the seven sites surveyed between 2015 and 2019. From another point of view, a possible effect of these non-native populations should be considered. The impact of this species outside its native range is, however, difficult to predict; the most probable is only its potential impact on the two native species of Viviparus. All three species differ somewhat in their habitat preferences in the Czech Republic, but $V$. acerosus ecologically overlaps with the other two species. $V$. viviparus is known mostly from rivers, while $V$. contectus prefers stagnant and overgrown habitats. However, V. acerosus was found mostly in transitional habitats between stagnant and flowing waters and often occupied muddy and slow-flowing canals and rivers in floodplains.

\section{ACKNOWLEDGEMENTS}

The authors would like to thank JAN VRBA for drawing maps, ALEKSANDRA RYSIEWSKA, IVA PospíšILOVÁ for photos and two anonymous reviewers for their valuable comments.

cation of parasitic infection in the species. American Malacological Bulletin 35: 175-180. https://doi. org/10.4003/006.035.0211

HorsÁK M., JUŘiČKOVÁ L., PICKA J. 2013. Měkkýši České a Slovenské republiky. Molluscs of the Czech and Slovak Republics. Kabourek, Zlín.

PIECHOCKI A., WAWRZYNIAK-WydROWSKA B. 2016. Guide to freshwater and marine Mollusca of Poland. Bogucki Wydawnictwo Naukove, Poznań.

RYSIEWSKA A., HOFMAN S., OSIKOWSKI A., BERAN L., PEŠIĆ. V., FALNIOWSKI A. 2019. Viviparus mamillatus (Küster, 1852), and partial congruence between the morphology- allozyme- and DNA-based phylogeny in European Viviparidae (Caenogastropoda: 
Architaenioglossa). Folia Malacologica 27: 43-51, https://doi.org/10.12657/folmal.027.004

Soes D. M., GlÖER P., WinTER A. J. de 2009. Viviparus acerosus (Bourguignat, 1862) (Gastropoda: Viviparidae), a new exotic snail species for the Dutch fauna. Aquatic Invasions 4: 373-375.

SZAROWSKA M., OSIKOWSKI A., HOFMAN S., FALNIOWSKI A. 2016. Pseudamnicola Paulucci, 1878 (Caenogastropoda: Truncatelloidea) from the Aegean Islands: a long or short story? Organisms Diversity \& Evolution 16: 121139. https://doi.org/10.1007/s13127-015-0235-5

VAVROVA L., VAN DAMME D. 2011. Viviparus acerosus. The IUCN Red List of Threatened Species 2011:
e.T23040A9408473. http://doi.org/10.2305/IUCN. UK.2011-2.RLTS.T23040A9408473.en

VINARSKI M. V., KANTOR Y. I. 2016. Analytical catalogue of fresh and brackish water molluscs of Russia and adjacent countries. A. N. Severtsov Institute of Ecology and Evolution of RAS, Moscow.

WELTER-SCHULTES F. W. 2012. European non-marine molluscs, a guide for species identification. Planet Poster Editions, Göttingen

Received: July 31st, 2019

Revised: August 6th, 2019

Accepted: August 7th, 2019

Published on-line: September 14th, 2019 